\title{
The native Florida Green Watersnake, Nerodia floridana (Goff 1936), preying upon the nonindigenous African Jewelfish, Hemichromis letourneuxi Sauvage 1880, in Florida
}

Kenneth L. Krysko', Stephen J. Walsh², and Robert H. Robins ${ }^{3}$

${ }^{1}$ Florida Museum of Natural History, Division of Herpetology, University of Florida, Gainesville, Florida 32611, USA (kenneyk@flmnh.ufl.edu) ${ }^{2}$ U.S. Geological Survey, Southeast Ecological Science Center, 7920 NW 71st Street, Gainesville, Florida 32653, USA (email: swalsh@usgs.gov) ${ }^{3}$ Florida Museum of Natural History, Division of Ichthyology, University of Florida, Gainesville, Florida 32611, USA (rhrobins@flmnh.ufl.edu)

$T_{1}$ he Florida Green Watersnake, Nerodia floridana (Goff 1936), is native to the southeastern United States from South Carolina to Florida (Conant and Collins 1998). In Florida, N. floridana (Fig. 1) has been documented throughout much of the state, including nearly all peninsular coun-

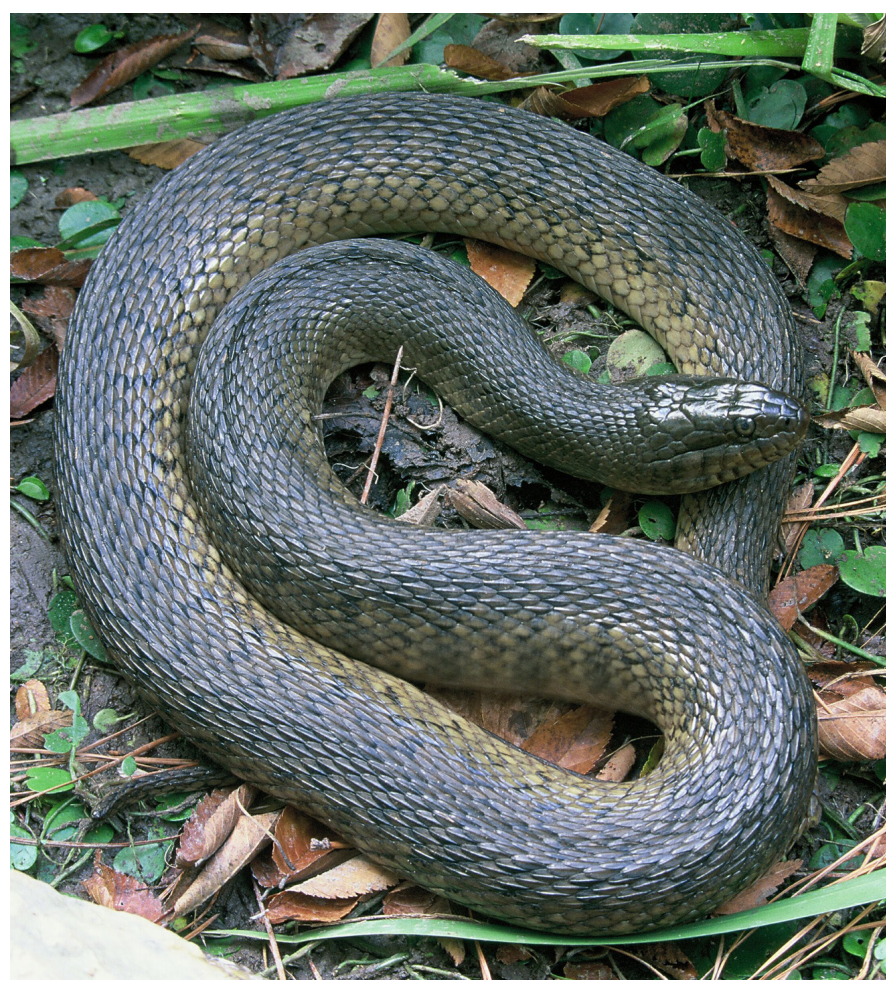

Fig. 1. The Florida Green Watersnake (Nerodia floridana) is known to consume invertebrates, fishes, frogs, salamanders, turtles, and even an alligator. Photograph by John Jensen. ties (Krysko et al. 2011). Nerodia floridana has been reported consuming invertebrates, fishes, frogs, salamanders, and turtles, without reference to specific species (Van Hyning 1932, Allen 1939, Jensen et al. 2008), Congo Eels, more commonly known as Two-toed Amphiumas (= Amphiuma means; Allen and Neill 1952), and the American Alligator (Alligator mississippiensis, Allen 1969). Additionally, Bancroft et al. (1983) reported that eight $N$. floridana from Lake Conway, Orange County, Florida, contained fish remains (principally centrarchids and poeciliids), one consumed a Greater Siren (Siren lacertina), and one contained the tail of an artificial purple fishing worm. Herein, we document $N$. floridana preying on the nonindigenous African Jewelfish, Hemichromis letourneuxi Sauvage 1880, in Florida.

On 16 January 1992, one of us (SJW) was electroshocking nonindigenous fishes and incidentally collected a neonate (213.1 mm SVL, $282.6 \mathrm{~mm}$ TL) female Nerodia floridana in a canal on the northeastern corner of US 41 and SR 826, Miami, Miami-Dade County, Florida $\left(25.76317^{\circ} \mathrm{N},-80.31965^{\circ} \mathrm{W}\right.$, WGS84; elev. $1 \mathrm{~m}$ ). This snake had obviously consumed a meal recently, and upon dissection it contained a nonindigenous Hemichromis letourneuxi (73 mm TL) in its stomach. The fish had been consumed head first. Both specimens were deposited in the Florida Museum of Natural History, University of Florida collections (Fig. 2; $N$. floridana = Herpetology UF 168052; H. letourneuxi = Ichthyology UF 184182). This is the first known record of this native snake preying on a nonindigenous fish in Florida. Hemichromis letourneuxi (Fig. 3) is native to and widely distributed in central and western Africa and obtains a maximum standard length of about $12 \mathrm{~cm}$ (Loiselle 1979). It was first reported as introduced to southern Florida 


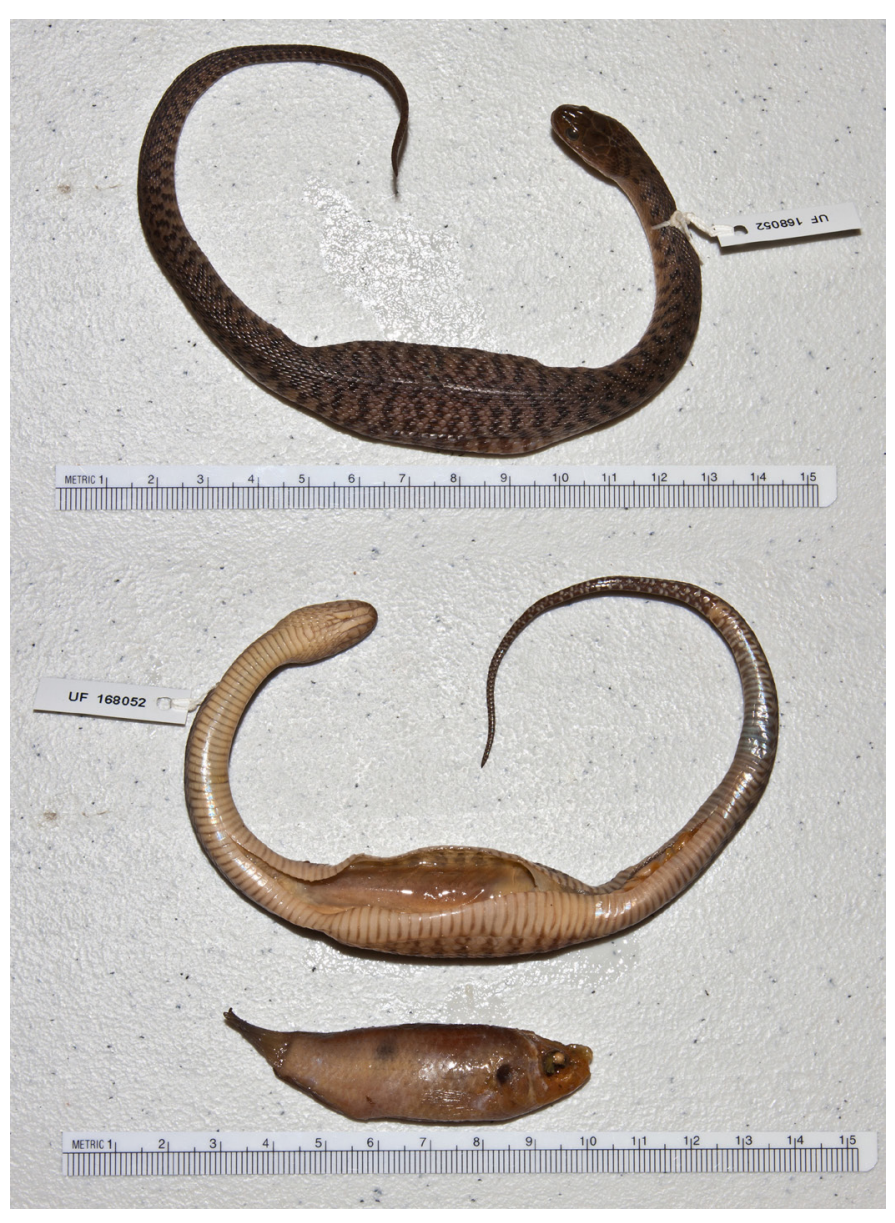

Fig. 2. Neonate Florida Green Watersnake (Nerodia floridana; UF 168052) with consumed nonindigenous African Jewelfish (Hemichromis letourneuxi; UF 184182) collected on 16 January 1992 in Miami, MiamiDade County, Florida. Photograph by Kenneth L. Krysko.

in 1965 (Rivas 1965) and is now widespread and abundant in canals, drainage ditches, streams, and wetlands throughout a large portion of southern Florida, including the Everglades (Fuller et al. 1999, Page and Burr 2011).

\section{Acknowledgments}

We thank Noel M. Burkhead, James D. Williams, Jayne C. Brim-Box, and Carter R. Gilbert for help with field work; Nicholas T. Coutu and Rebecca Reichart for assistance with photography; Noel M. Burkhead for the photograph of

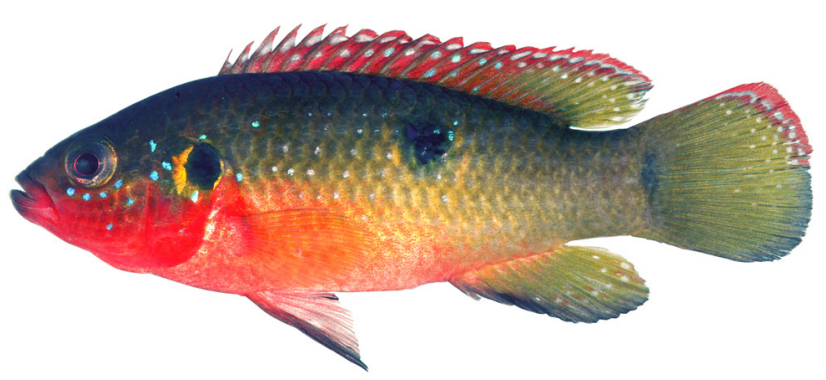

Fig. 3. An African Jewelfish (Hemichromis letourneuxi). Photograph by Noel M. Burkhead.

Hemichromis letourneuxi; J. Steven Godley for literature references; and Robert Powell and an anonymous reviewer for helpful comments on this paper.

\section{Literature Cited}

Allen, E.R. 1939. Notes on Florida water snakes. Proceedings of the Florida Academy of Sciences 3:101-104.

Allen, E.R. 1969. Why save the alligator. Presented to Conservation 70s Inc. Environmental Legislative Workshop, Panel No. 4, Wildlife Resources, Homosassa Springs, Florida, USA (printed by the International Crocodilian Society, Silver Springs, Florida, USA).

Allen, E.R., and W.T. Neill. 1952. The water snake. Florida Wildlife 6:13, 39.

Bancroft, G.T., J.S. Godley, D.T. Gross, N.N. Rojas, D.A. Sutphen and R.W. McDiarmid. 1983. Large-scale operations management test of use of the White Amur for control of problem aquatic plants. The herpetofauna of Lake Conway: Species accounts. Final report. Miscellaneous Paper A-83-5, U.S. Army Engineers Waterways Experiment Station, CE, Vicksburg, Mississippi, USA.

Conant, R. and J.T. Collins. 1998. A Field Guide to Reptiles and Amphibians of Eastern and Central North America. 3rd edition, expanded. Houghton Mifflin, Boston, Massachusetts, USA.

Fuller, P.L., L.G. Nico, and J.D. Williams. 1999. Nonindigenous Fishes Introduced into Inland Waters of the United States. American Fisheries Society Special Publication 27, Bethesda, Maryland.

Jensen, J.B., C.D. Camp, W. Gibbons, and M.J. Elliott (eds.). 2008. Amphibians and Reptiles of Georgia. University of Georgia Press, Athens, Georgia, USA.

Krysko, K.L., K.M. Enge, and P.E. Moler. 2011. Atlas of Amphibians and Reptiles in Florida. Final Report, Project Agreement 08013, Florida Fish and Wildlife Conservation Commission, Tallahassee, Florida, USA.

Loiselle, P.V. 1979. A revision of the genus Hemichromis Peters 1858 (Teleostei: Cichlidae). Annales Serie in 8 Sciences Zoologiques 228. Museé Royal de L'Afrique Central, Tervuren, Belgique.

Page, L.M. and B.M. Burr. 2011. A Field Guide to Freshwater Fishes: North America North of Mexico. Houghton Mifflin Company, New York, New York, USA.

Rivas, L.R. 1965. Florida freshwater fishes and conservation. Quarterly Journal of the Florida Academy of Sciences 28:255-258.

Van Hyning, O.C. 1932. Food of some Florida snakes. Copeia 1932:37. 